\title{
Identification of patchouli oil components distilled using ultrasonic waves
}

\author{
D Ermaya $^{1^{*}}$, YR Widodo ${ }^{2}$, Shintawati ${ }^{1}$ and Syadilla $\mathrm{A}^{\mathbf{1}}$ \\ ${ }^{1}$ Industrial Chemical Engineering Technology Study Program, Department of \\ Agricultural Technology, Politeknik Negeri Lampung, Bandar Lampung, Indonesia \\ 2 Food Technology Study Program, Department of Agricultural Technology, \\ Politeknik Negeri Lampung, Bandar Lampung, Indonesia
}

*Corresponding author: dewi.ermaya@ polinela.ac.id

\begin{abstract}
Patchouli oil identification using ultrasonic waves is carried out using sonic tools. This treatment is done on distilled patchouli oil. The addition of ultrasound waves aims to increase the alcohol patchouli component and identify the patchouli oil component after sonification. The use of ultrasonic waves of $40 \mathrm{kHz}$. The variables used in this study were ultrasonic wavelengths, namely 20,30 , and 40 minutes, and temperatures of $35^{\circ} \mathrm{C}, 40{ }^{\circ} \mathrm{C}$, and $45{ }^{\circ} \mathrm{C}$. The results obtained were analyzed using GCMS. The analysis showed that there was an increase in the number of alcohol patchouli before and after the use of ultrasonic waves. From the results of the study, the length of time using ultrasonic significantly affected the patchouli alcohol content and patchouli oil components.
\end{abstract}

\section{Introduction}

Essential oils are substances that give the aroma of plants. Essential oils have volatile components in some plants with certain characteristics. Currently, essential oils have been used as perfumes, cosmetics, food additives, and medicines [1]. Patchouli oil is classified as an essential oil (minyak atsiri) and is an important component in the perfume industry such as fragrances, soaps, deodorants, cosmetics, and others. Patchouli oil contains chemical compounds that act as a fixation agent. Until now, there are no synthetic products for patchouli oil obtained from patchouli (Pogostemon patchouli) so that the cosmetics industry's dependence on patchouli oil is still very high [2].

The use of patchouli oil in these industries is due to its high fixability to other fragrance ingredients, its aroma-binding properties so it lasts a long time because it can bind fragrant odors and prevent fragrance evaporation. The quality of patchouli oil produced from refining must meet the criteria for trade quality standards by the Indonesian National Standard (SNI-06-2385-2006). The components of patchouli oil include patchouli alcohol which is the most important component. Patchouli alcohol is Patchouli alcohols are oxygenated sesquiterpenes, having a molecular weight 224 with the molecular formula $\mathrm{C} 15 \mathrm{H} 26 \mathrm{O}$ and has a boiling point of $140{ }^{\circ} \mathrm{C}$ at a pressure of $8 \mathrm{mmHg}$ (Bulan, 2000). The problem in the development of patchouli oil in Indonesia is a low quality and oil content so that a refining process is needed to increase the selling value and product quality. The aim of the study is only to increase the component of patchouli oil, namely patchouli alcohol. GC-MS analysis is used to determine the chemical components contained in patchouli oil._ There have been 
many studies related to oil refining until now, including fractionation, vacuum, oil $\mathrm{pH}$ changes, and the combination of processes.

Based on research, a new technique for the separation process using ultrasonic waves has been developed. [3] the research has developed ultrasonic-assisted extraction of palm oil waste. The main advantages of extraction with the help of ultrasonic waves compared to conventional separation processes using the Soxhlet are greater efficiency and shorter operating time. The conventional separation process using organic solvents generally takes a long time because of its low mass transfer rate. Onion extraction research was carried out by combining the Microwave Steam Diffusion (MSDf) method with the addition of ultrasonic waves. There was an increase in the yield of MUSDf due to the added ultrasonic waves during the maceration process. The energy from this ultrasonic wave will pass through the water as an intermediary to make contact with the material. Ultrasonic waves which have this energy will cause the phenomenon of cavitation [4].

Based on the description above, the process and purification that can increase the composition and component acquisition can be done by combining the separation or refining process to increase the patchouli alcohol in patchouli oil using an ultrasonic tool. So that the quality is better and the selling value increases.

\section{Methods}

This research was conducted in the Chemical Analysis Laboratory, Lampung State Polytechnic. GCMS analysis was carried out in the Lhokseumawe State Polytechnic Instrumentation Laboratory.

\subsection{Materials and Tools}

The materials used for the research were patchouli oil from the distillation of Pogestemon cablin Bent from the Aceh Barat Daya area (ABDYA), alcohol, and tap water. The tools used in this research are analytical balance, measuring cup, condenser, measuring flask, dropper, burette, Erlenmeyer, beaker, 5 $\mathrm{ml}$ pycnometer, thermometer, spatula, refractometer, oven, sonic BRANSON 5800, and GCMSShimadzu model.

\subsection{Patchouli Oil Sonification Process.}

$200 \mathrm{ml}$ of patchouli oil was distilled in ultrasonic equipment (free variable T), sonification time (free variable) and sonification (40kHz) (fixed variable) with variations in temperature $(\mathrm{S})\left(30^{\circ} \mathrm{C}, 40^{\circ} \mathrm{C}\right.$, $\left.50^{\circ} \mathrm{C}\right)$, distillation time (T) $(20$ minutes, 30 minutes and 40 minutes). The research was conducted in a chemical analyst laboratory, Lampung State Polytechnic. Furthermore, the results obtained were carried out by physical analysis and analysis of patchouli oil content by GC-MS. In Lhokseumawe State Polytechnic laboratory instrument, the chemical composition analysis in patchouli oil was identified using a set of tools Gas Chromatography-Mass Spectroscopy (GC-MS) Shimadzu model.

\section{Results and Discussion}

The addition of ultrasonic waves to the continued distillation of patchouli oil aims to increase the content of patchouli alcohol (PA) resulting from this process with a short time of 20 minutes and temperature. The use of ultrasonic waves is appropriate for extracting natural materials that have a high level of sensitivity to temperature changes. The increasing percentage of patchouli oil after adding ultrasonic waves can be seen in Figure 1 below: 


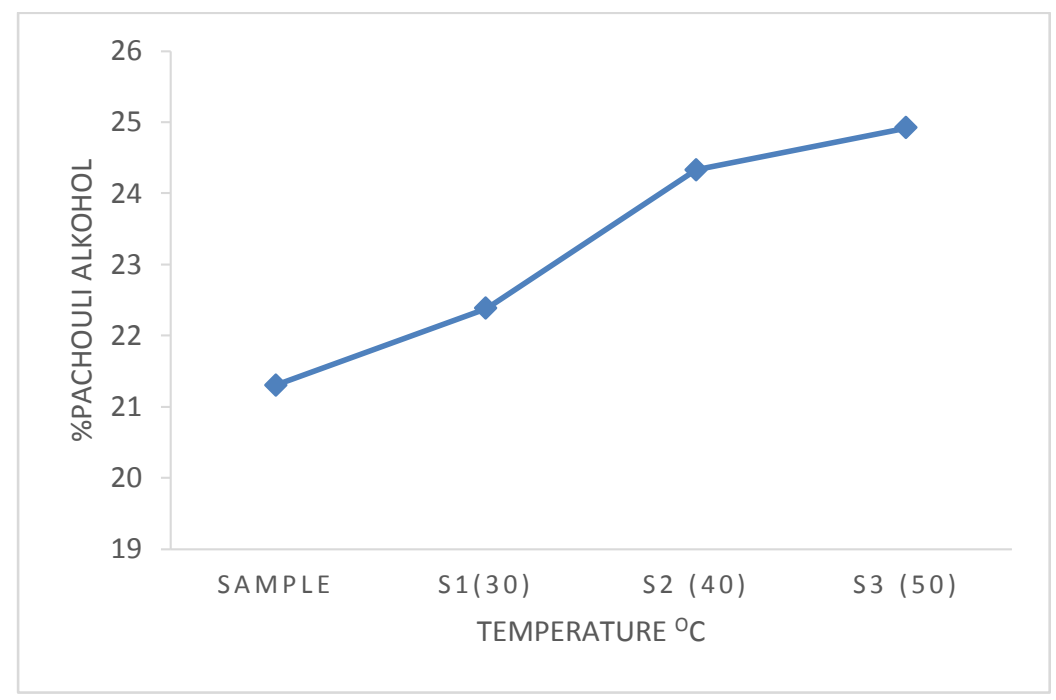

Figure 1. Graph of the relationship between temperature and patchouli alcohol levels after sonification

From Figure 1, it can be seen that the percentage of increase in alcohol patchouli, which was initially $21.30 \%$ (sample) before the addition of ultrasonic waves increased with the highest percentage an average of $24.92 \%$ at a temperature of $50^{\circ} \mathrm{C}$. An increase happens after the addition of ultrasonic waves. The lowest alcohol patchouli percentage at a temperature of $30^{\circ} \mathrm{C}$ is $22.38 \%$ in 20 minutes $(p>0,05)$. There is an effect of ultrasonic wave addition on the increase of alcohol patchouli. Determination of the chemical composition of patchouli oil is from the results of the analysis by GCMS obtained the components of the chemical compounds contained in the patchouli oil sample. The chromatogram of the chemical components of patchouli oil is shown in Figure 2.

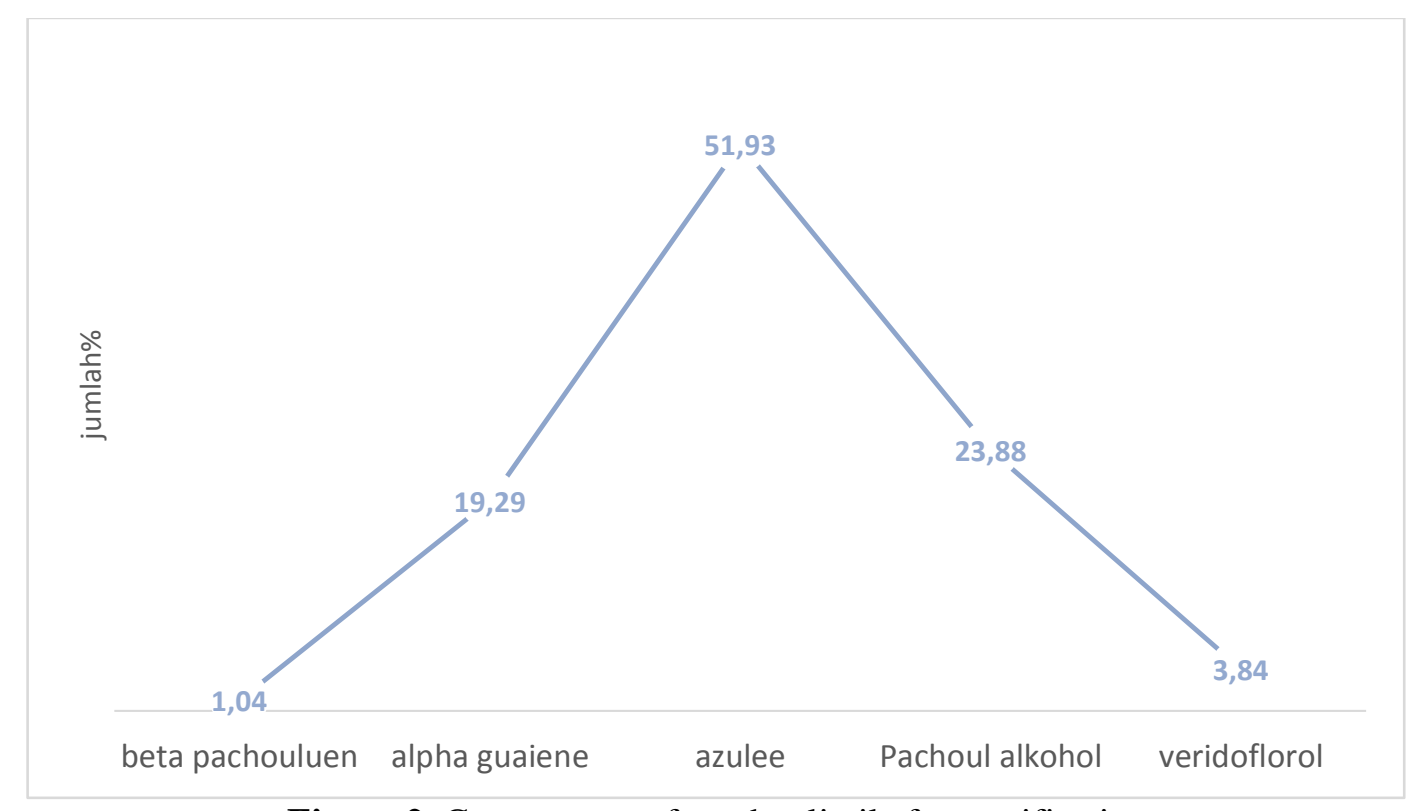

Figure 2. Components of patchouli oil after sonification

Reading the data from the chromatogram shows that the chemical compounds contained in the identified patchouli oil samples are beta-pachouluen, alpha guaiene, azuluen, pachoul alcohol, and veridoflorol. 
Based on the results of the analysis using GC-Ms, the acquisition of alcohol patchouli (PA) which is a very important ingredient, based on the SNI requirements for alcohol patchouli (PA) for patchouli oil at least $31 \%$ does not fulfill the standard yet. After being treated with ultrasonic waves by varying the time and temperature, the average PA yield was 24.92 . Namely at a temperature of $50^{\circ} \mathrm{Cby}$ by using $40 \mathrm{KHz}$ sonic or ultrasonic waves for 40 minutes. Based on the GC-MS test results, PA has the highest pick.

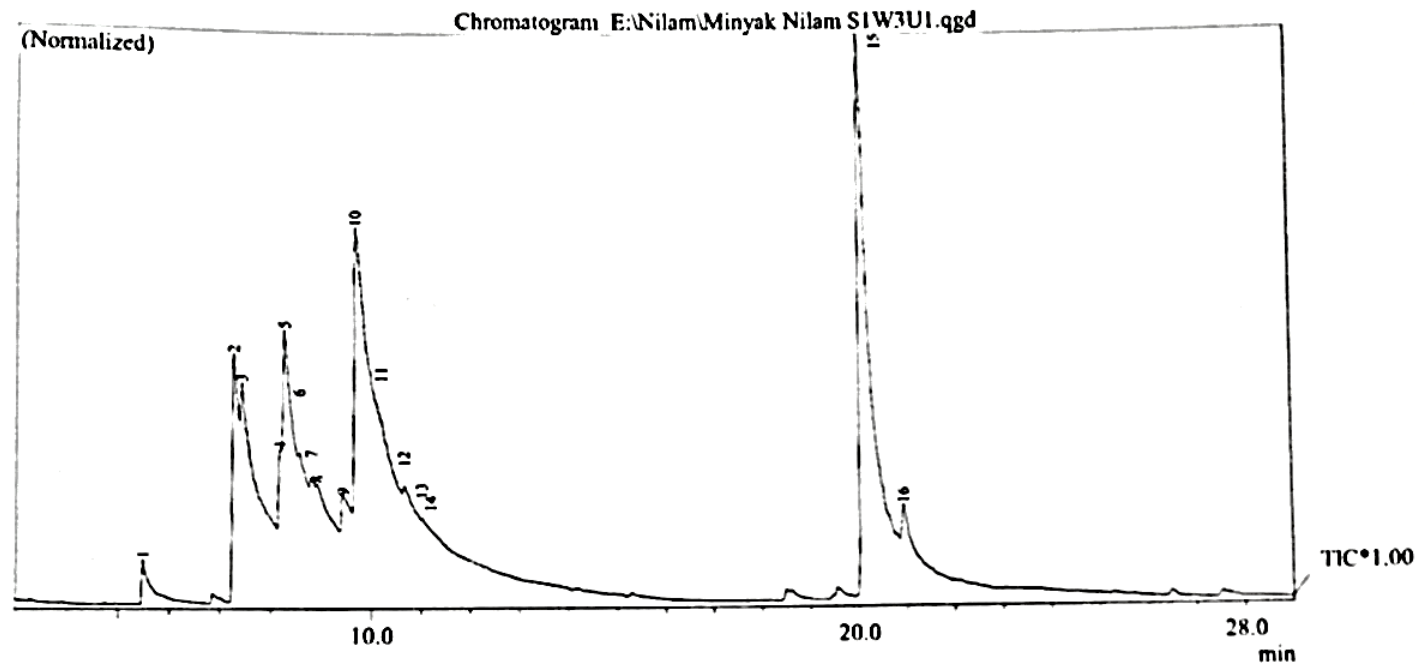

Figure 3. Results of GCMs analysis after sonification

Based on the results of GC MS patchouli oil sonic results obtained patchouli oil after being dyed has 16 components and the alcohol patchouli (PA) is at the 15th Pic. In this study, there was a change in the number of components and composition after sonification. The results of the study using sonic showed an increase in the number of alcohol patchouli (PA) at changes in time and it does not affect by temperature. In addition to the enhancement of alcohol patchouli (PA) sonic, ultrasonic waves also change the component by which azzuluen increases. The use of ordinary alcohol patchouli (PA)is a fixative agent for binding perfumes. While azzuluen is an anti-hanging ingredient in cosmetics. The use of patchouli oil in the industry is due to its high fixability to fragrance so that the aroma lasts a long time, so it can bind fragrance and prevent the fragrance from evaporating [2].

\section{Conclusion}

Based on the results of the research that has been done, it can be concluded that the addition of ultrasonic waves can increase the percentage of patchouli oil based on the results of the analysis by GC-Ms. Namely, from 21.30 to 24.92 at a temperature of $50^{\circ} \mathrm{C}$ and length of time for 40 minutes. With the increase in the PA value, the selling value also increases. The need for a method to isolate patchouli oil components is an effort to classify the patchouli oil components resulting from the addition of ultrasonic waves. Moreover, process optimization using ultrasonic waves is also required.

\section{Acknowledgments}

Thank you to the Lampung State Polytechnic Research and Community Service Unit (UPPM POLINELA) for funding this research until its completion, through the DIPA POLINELA 2020 funds. We also would like to say thank you to the Lampung State Polytechnic(POLINELA) Chemical Analysis Laboratory and the Lhokseumawe State Polytechnic Instrument Laboratory and all the people who played a role and give a hand in this research. 


\section{References}

[1] Bulan, R. (2000). Isolasi, Identifikasi dan Sintesis Turunan Patchouli Alkohol dari Minyak Nilam. Tesis Fakultas Matematika dan Ilmu Pengetahuan Alam. Universitas Gadjah Mada, Yogyakarta

[2] Buchbauer, G., W. Jager, H. Dietrich, , Ch. Plank, and E. Karamat. 1991. Aromatherapy: Evidence for Sedative Effects of Essential Oil of Lavender after Inhalation. Journal of Biosciences; 46c, 1067-1072.

[3] Zaimah, S. 2014. PENGUJIAN KUALITAS DAN KOMPOSISI KIMIA MINYAK NILAM (Pogostemon cablin benth) SETELAH PENYIMPANAN. Indonesian Journal of Chemical Research - Indo.J.Chem.Res. Volume 2. NO.1

[4] Dani, M. Supardan, Teku, M. Asnawi, Putri, Y., Wahyuni, S.. METODE EKSTRAKSI PELARUT BERBANTUAN ULTRASONIK UNTUK RECOVERY. AGRITECH, Vol. 31, No. 4, NOVEMBER 2011

[5] Ferdiansyah, A., Islamiyah W., Rosita, N. Asri, 2010, Ekstraksi Minyak Atsiri Dari Bawang Merah Dengan Metode Microwave Ultrasonic Steam Diffusion (MUSDf). Akta Kimindo Vol. 4(2), 2019: 86-94.

[6] Khan, M. K., Vian, M. A., Tixier, A. S., Chemat, F., \& Dangles, O. (2010). Ultrasound-Assisted Extraction of Polyphenols (Flavanone Glycosides) from Orange (Citrus sinensis L.) Peel. Food Chemistry, 851-858.

[7] Liu, Q. M., Yang, X. M., Zhang, L., \& Majetich, G. (2010). Optimization of UltrasonicAssisted Extraction of Chlorogenic Acid from Folium eucommiae and Evaluation of its Antioxidant Activity. Journal of Medicinal Plants Research Vol. 4 (23), 2503-2511.

[8] Muchtaridi. 2005. Penelitian Pengembangan Minyak Atsiri Sebagai Aromaterapi Dan Potensinya Sebagai Produk Sediaan Farmasi. Fakultas Farmasi, Universitas Padjadjaran. Jurnal Teknologi Industri Pertanian 17.3 80-88. 